\title{
Mycorrhizae, elemental sulfur and phosphorus effects on pepper yield and nutrient uptake
}

Mikoriza, elementer kükürt ve fosforun biber verimi ve besin elementi alımı üzerine etkileri

Hüseyin KARACA ${ }^{1}$

${ }^{1}$ Hatay Mustafa Kemal University, Faculty of Agriculture, Soil Science and Plant Nutrition Department, Antakya-Hatay, Turkey.

MAKALE BILGISI / ARTICLE INFO

Makale tarihçesi / Article history:

DOI: $10.37908 /$ mkutbd.638312

Geliş tarihi /Received:25.10.2019

Kabul tarihi/Accepted:17.02.2020

\section{Keywords:}

Mycorrhizae; elemental sulfur; phosphorus; shoot nutrient concentrations; pepper yield.

\footnotetext{
Corresponding author: Hüseyin KARACA

$\bowtie$ : hkaraca@mku.edu.tr
}

\section{ÖZET / A B STR A C T}

Atıf / Citation: Karaca H (2020) Mycorrhizae, elemental sulfur and phosphorus effects on pepper yield and nutrient uptake. MKU. Tar. Bil. Derg. 25(3) : 300-308. DOI: 10.37908/mkutbd.638312

\section{INTRODUCTION}

Fertilization is common practice to increase yield in agriculture all over the world. For that reason various commercial fertilizers are applied in agricultural production system same as mycorrhizae as biological fertilizer.

Mycorrhizae (Mohammed et al., 2004; Al-Karaki, 1998), P (Antunes and Cardoso, 1991; Karaca, 2012a) and elementel S addition (Karaca, 2012a) results in significant yield increases. Oxidation products of ES decreases soil $\mathrm{pH}$ that gradually increases solubility of plant nutrients for the plant uptake to result in higher growth. However, heavy metal concentration, if present, can increase by the decreased soil $\mathrm{pH}$ resulting in yield decrease (Karaca et al., 2013; Cui et al., 2004).

Combined treatment of ES and P fertilizers affect the yield in both ways. In that respect, it was reported that 
ES and $\mathrm{P}$ combination compared to their individual addition significantly increased the root yield but the shoot yield remained unchanged (Karaca, 2012a). On the other hand, significant yield decreases were reported by $\mathrm{ES}$ and $\mathrm{P}$ combination compared to $\mathrm{P}$ addition alone (Karaca, 2012b).

There was no correlation all the time between the yield and shoot nutrient concentrations (Karaca, 2012a; Karaca, 2012b; Yibirin et al., 1996).

Mycorrhizal inoculation alone compared to the control treatment results in increased or did not change the root to shoot ratio. However, those ratios change in both directions in the case of ES and/or P additions (Karaca, 2012a; Karaca, 2012b). Accordingly, there are no correlations all the time between the yield and the root to shoot ratio (Karaca, 2014). Romero et al. (1986) proposed that there may be an optimum $\mathrm{R}$ : $\mathrm{S}$ ratio for plant growth.

The $\mathrm{P}$ fertilization to a $\mathrm{P}$ deficit soil decreases root mycorrhizal infection level, wherease ES treatment can compensate the decreased level resulted from the $\mathrm{P}$ fertilization (Karaca, 2012a).

A slight reduction on percentage of mycorrhizal colonization was noted with $\mathrm{SO}_{2}$ (Diaz et al., 1996). This study evaluates the effect of ES and/or P on mycorrhizae for the yield, shoot nutrient concentrations for pepper in the loam textured, $\mathrm{P}$ deficient soil under greenhouse growth conditions.

\section{MATERIAL and METHOD}

Surface soil samples $(0-30 \mathrm{~cm})$ for Karaburun soil were taken from the non cultivated part of the Cukurova University experimental farm. The soils, Karaburun serial was a typic Xerorthent of the Entisol ordo in the Soil Taxonomy (Ozbek et al., 1974). The plot had not been cultivated for many years. Air dried soil samples were crushed, sieved ( $2 \mathrm{~mm}$ mesh opening) and autoclaved at $121^{\circ} \mathrm{C}$ for two hours prior to use as a growth medium. The pots surfaces were sterilized with ethanol $96 \%(\mathrm{v} / \mathrm{v})$, washed by distilled water and dried out prior to the use. $4 \mathrm{~kg}$ of autoclaved soil were placed in the plastic pots and following treatments were made;

MoPoSo: Control treatment in which soil amended with $500 \mathrm{mg} \mathrm{kg}^{-1} \mathrm{~N}$ (as urea), $250 \mathrm{mg} \mathrm{kg}^{-1} \mathrm{~K}$ (as KNO${ }_{3}$ ), $5 \mathrm{mg} \mathrm{kg}^{-}$ ${ }^{1} \mathrm{Zn}\left(\right.$ as $\mathrm{ZnSO}_{4}$ ) and $20 \mathrm{mg} \mathrm{kg}^{-1} \mathrm{Fe}$ (as Fe-EDDHA) and then soil samples were thoroughly mixed to have homogenous distribution of nutrients.

MoPoS+: Control + $100 \mathrm{mg} \mathrm{kg}^{-1} \mathrm{ES}$.

MoP+So: Control $+100 \mathrm{mg} \mathrm{kg}^{-1} \mathrm{P}$ (as triple super phosphate).

MoP+S+: Control + $100 \mathrm{mg} \mathrm{kg}^{-1} \mathrm{P}+100 \mathrm{mg} \mathrm{kg}^{-1} \mathrm{ES}$.
M+PoSo: Glomus mossea AM fungi type as the mycorrhizae (as $145 \mathrm{~g}$ soil taken from the vicinity of the dead vineyard roots at the University Farm for the average 1000 spore/pot inoculation) was added to the control treatment. The mycorrhizal density of soil was determined by the method of Gerdemann and Nicolson (1963).

M+PoS+: Control + the mycorrhizae $+100 \mathrm{mg} \mathrm{kg}^{-1} \mathrm{ES}$. $\mathrm{M}+\mathrm{P}+\mathrm{So}$ : Control + the mycorrhizae $+100 \mathrm{mg} \mathrm{kg}^{-1} \mathrm{P}$. $\mathrm{M}+\mathrm{P}+\mathrm{S}+$ : Control + the mycorrhizae $+100 \mathrm{mg} \mathrm{kg}^{-1} \mathrm{P}+100$ $\mathrm{mg} \mathrm{kg}^{-1} \mathrm{ES}$.

All fertilizers were mixed thoroughly in the soil to have homogenous distribution. However, the mycorrhizal inoculum was mixed into the top $5 \mathrm{~cm}$ of the soil. Following the addition of the inoculum, $1000 \mathrm{ml}$ water was added to the each pot to bring the soil about field capacity and allowed to drain for 5 days.

Commercial green pepper seeds (Capsicum annuum L.) were sown into sterilized growth medium of soil and organic matter mixture (soil/organic matter: $2 / 1(\mathrm{v} / \mathrm{v})$ and grown for 35 days. The seedlings were carefully extracted from the nursery and transplanted into the pots in the same greenhouse and irrigated when required. The seedlings grew for one and half month. The plants were harvested by cutting just above the soil surface and the shoots were separately dried at $75^{\circ} \mathrm{C}$ to a constant weight after clearing possible contaminants by tap water and then distilled water respectively. Plants dry were grinded to a particle size below $0.5 \mathrm{~mm}$ to obtain homogenous alicot.

Nitrogen $(N)$ content of samples was determined by Kjeldahl digestion and steam distillation (Lees, 1971). For determination of other nutrient elements samples were digested in $\mathrm{HNO}_{3}$ and $\mathrm{H}_{2} \mathrm{O}_{2}$ (v/v: 4/1) mixture (Cem, MarsXpress Manual). Phosphorus concentration of the digests were colorimetrically determined (Shimadzu 1201 model UV/VIS spectrometer) according to Murphy and Riley (1962) and potassium (K), sodium ( $\mathrm{Na})$, calcium $(\mathrm{Ca})$, magnesium $(\mathrm{Mg})$, iron $(\mathrm{Fe})$, copper $(\mathrm{Cu})$, mangenese $(\mathrm{Mn})$ and zinc $(\mathrm{Zn})$ concentration were determined using ICP-AES (Varian, Liberty Series II) according to Kacar (1972).

After separating from the soil, the fresh roots were washed under running tap water, followed by distilled water and dried on tissue paper. Then the root biomasses were determined. Fine roots were freshly preserved in a mixture (250:13:15 v/v) of ethanol, glacial acetic acid and formalin (Ortas et al., 2004) until the determination of mycorrhizal infection. The root clearing and staining procedure and the degree of mycorrhizal infection in the root cortex was assessed by the method of Koske and Gemma (1989). 
Basic physical and chemical properties of autoclaved soil were analyzed as follows: soil texture analysis by a hydrometer (Bouyoucos, 1951), organic matter by using Lichterfelder wet ashing (Schlichting and Blume, 1966), soil reaction and electrical conductivity by means of a combined electrode and EC meter in saturation paste, respectively (Schlichting and Blume, 1966), Ca carbonate equivalent by a manometric method (Loeppert and Suarez, 1996), cation exchange capacity (CEC) by saturating sodium acetate $(1 \mathrm{M} \mathrm{pH} 8.2)$ and then replacing the $\mathrm{Na}$ with ammonium acetate $(1 \mathrm{M} \mathrm{pH} 7.0)$ (U.S. Salinity Laboratory Staff, 1954), available phosphorus by Olsen method (Olsen et al., 1954), total nitrogen (N) by Bremner (1996), soil nitrate by Fabig (1978), soil ammonium by Fachgruppe Wasserchemie in der Gesellscheft Deutscher Chemiker (1983), exchangeable potassium (K) with neutral ammonium acetate by Pratt and Morse (1954), DTPA extractable microelements ( $\mathrm{Fe}, \mathrm{Zn}, \mathrm{Cu}$ and $\mathrm{Mn}$ ) by Lindsay and Norvell (1978), soil density by a picnometer by Blake and Hartge (1986b), bulk density by Blake and Hartge (1986a) and permeability by a constant head permeameter by Klute and Dirksen (1986).

The Karaburun soil series is classified as a clay loam textured soil (sand $312.5 \mathrm{~g} \mathrm{~kg}^{-1}$; silt $390.2 \mathrm{~g} \mathrm{~kg}^{-1}$; clay $\left.297.3 \mathrm{~g} \mathrm{~kg}^{-1}\right)$. The $\mathrm{pH}$ of the soil is slightly alkaline (7.44) and there is no salinity problem $\left(\mathrm{EC}=0.85<\mathrm{dSm}^{-1}\right)$. The organic matter content is low $\left(14.2 \mathrm{~g} \mathrm{~kg}^{-1}\right)$, while the CEC is $43.71 \mathrm{cmol} \mathrm{kg}^{-1}$, density is $2.67 \mathrm{~g} \mathrm{~cm}^{-3}$; bulk density is $1.456 \mathrm{~g} \mathrm{~cm}^{-3}$; porosity $45.4 \%$ calculated from bulk density and density; and the permeability is $2.8 \mathrm{~cm} \mathrm{~h}^{-1}$ (medium). The plant nutrients of the soil are low: $\mathrm{P} 4.48 \mathrm{mg} \mathrm{kg}^{-1} ; \mathrm{K}$ $140 \mathrm{mg} \mathrm{kg}^{-1} ; \mathrm{NH}_{4} 3.86 \mathrm{mg} \mathrm{kg}^{-1} ; \mathrm{NO}_{3} 1.85 \mathrm{mg} \mathrm{kg}^{-1}$; $\mathrm{Fe}$ $0.145 \mathrm{mg} \mathrm{kg}^{-1}$; Cu $0.084 \mathrm{mg} \mathrm{kg}^{-1}$; Mn $0.478 \mathrm{mg} \mathrm{kg}^{-1}$ and $\mathrm{Zn}$ $0.125 \mathrm{mg} \mathrm{kg}^{-1}$. Soil is very calcareous with $425 \mathrm{~g} \mathrm{~kg}^{-1}$ $\mathrm{CaCO}_{3}$ content .

The data were subjected to the analysis of variance using MSTAT-C statistical analysis package (MSTATC, Michigan State University, East Lansing, MI, USA). The mean separation was made by Least Significant Difference (LSD) test at $p=0.05$.

\section{RESULTS and DISCUSSION}

\section{Shoot and Root Yield, and Shoot Nutrient Concentrations}

MoPoS+ treatment compared to the MoPoSo treatment increased shoot and root biomasses (Table 1, Figure 1) being in parallel with the previous findings (Karaca, 2012a) with increased shoot $P$ and $M g$ concentration and decreased shoot Fe and Mn concentration (Figure 2,3). Those yield increases can be attributed to solubilizing effect of ES fertilization for the nutrients in a growth medium. Similar yield increases were obtained by $\mathrm{MoP}+\mathrm{So}$ treatment compared to the control treatment being in line with the previous findings (Antunes and Cardoso, 1991) accompanied by the increased shoot $P$, $\mathrm{Ca}, \mathrm{Mg}, \mathrm{Fe}, \mathrm{Zn}$ and $\mathrm{Mn}$ concentrations and decreased shoot $\mathrm{Cu}$ concentration. Those yield increases can be expected by $\mathrm{P}$ fertilization, some to a great extent, in $\mathrm{P}$ deficient soils. On the other hand, MoP+S+ treatment compared to MoP+So treatment significantly decreased the shoot and root yield (Table 1 and Figure 1) being consistent with the previous findings (Karaca, 2012b; Cui et al., 2004) with the increased shoot $\mathrm{Ca}, \mathrm{Mg}, \mathrm{Mn}$ concentrations and decreased shoot $\mathrm{P}, \mathrm{Fe}, \mathrm{Zn}$ and $\mathrm{Cu}$ concentrations (Figure 2,3). Those yield decreases can be resulted in excessive accumulation of $\mathrm{Mn}$ and nutrient imbalances in shoots depending on the S-induced $\mathrm{pH}$ decreases in the rhizosphere. Thus, there is no correlation all the time between the yield and shoot nutrient concentrations among the treatments. Shoot nutrient concentrations can independently change in both directions due to more complex interactions of nutrient elements in soil and different plant tissue (Karaca, 2012a; Karaca, 2012b; Yibirin et al., 1996).

M+PoSo treatment compared to MoPoSo treatment significantly increased shoot and root yield (Table 1 and Figure 1) being in line with the mycorrhizal infection (Mohammed et al., 2004; Al-Karaki, 1998) that resulted in the increased shoot $\mathrm{P}, \mathrm{Mg}, \mathrm{Ca}, \mathrm{Zn}, \mathrm{Mn}$ concentrations and decreased shoot $\mathrm{Fe}$ and $\mathrm{Cu}$ concentrations (Figure 2,3 ). Those yield increases can be attributed to enhanced nutrient uptake by the plant root infected with mycorrhizae. Mycorrhizal infection increases the rootsurface contact surface area which enable to enhanced nutrient uptake. On the contrary, M+PoS+ treatment compared to the M+PoSo treatment significantly decreased the shoot and root yield due possibly to excessive uptake of $\mathrm{Fe}, \mathrm{Zn}$ and $\mathrm{Mn}$ and reduced concentrations of $\mathrm{P}, \mathrm{Ca}, \mathrm{Mg}$ and $\mathrm{Cu}$ in plant tissues. In a similar way, it was reported that such yield decrease may be related to the mimic of heavy metal toxicity (Cui et al., 2004; Karaca, 2014).

Similar yield decreases were obtained by $\mathrm{M}+\mathrm{P}+\mathrm{So}$ treatment compared to the M+PoSo treatment. This fact is indicating that yield decreases was caused by the antagonistic relation between mycorrhizae and phosphorus fertilization. On the other hand, there were significantly higher accumulation of $\mathrm{P}, \mathrm{Ca}, \mathrm{Mg}, \mathrm{Fe}, \mathrm{Zn}$ and $\mathrm{Mn}$ with reduced $\mathrm{Cu}$ concentrations in plant tissue for the $\mathrm{M}+\mathrm{P}+\mathrm{So}$ treatment compared to $\mathrm{M}+\mathrm{PoS}$ o treatment (Table 1 and Figure 2,3). That yield decrease is in accordance with the previous findings (Cui et al., 2004; 
Karaca, 2014) and indicating an accumulation effect due possibly to deficiency of any other element.

$\mathrm{M}+\mathrm{P}+\mathrm{S}+$ treatment compared to $\mathrm{M}+\mathrm{P}+\mathrm{So}$ treatment increased the shoot and root yields in the mycorrhizal treatments. Those yield increases can be attributed to differences of the shoot nutrient concentrations, too.
Thus, the shoot $\mathrm{P}$ concentration significantly increased while the shoot $\mathrm{Ca}, \mathrm{Mg}, \mathrm{Fe}, \mathrm{Zn}$ and $\mathrm{Mn}$ concentration significantly decreased for the $\mathrm{M}+\mathrm{P}+\mathrm{S}+$ treatment compared to the $\mathrm{M}+\mathrm{P}+\mathrm{So}$ treatment. However, the shoot $\mathrm{Cu}$ concentration was remained constant.

Table 1. Response of pepper to different treatments in Karaburun soil

\begin{tabular}{|c|c|c|c|c|c|c|c|}
\hline Treatment & $\begin{array}{c}\text { Shoot DW } \\
(\mathrm{mg})\end{array}$ & $\begin{array}{c}\text { Root DW } \\
(\mathrm{mg})\end{array}$ & $R / S$ & $\begin{array}{c}\text { Mycorrhizal } \\
\text { infection (\%) }\end{array}$ & $\begin{array}{c}\text { N (mg kg- } \\
1^{-}\end{array}$ & $P\left(\mathrm{mg} \mathrm{kg}^{-1}\right)$ & $\begin{array}{c}\mathrm{K}(\mathrm{mg} \mathrm{kg} \\
1)\end{array}$ \\
\hline MoPoSo & 241.67e & $25.00 d$ & $0.10 c$ & 0.00 & 46783.33 & $1533.33 \mathrm{~g}$ & 16018.07 \\
\hline MoP+So & 1183.33a & $213.33 a$ & $0.18 a b$ & 0.00 & 46523.33 & $2566.67 a$ & 18351.76 \\
\hline MoPoS+ & 282.33de & $28.67 \mathrm{~cd}$ & $0.10 c$ & 0.00 & 47496.67 & $1866.67 e$ & 16187.49 \\
\hline MoP+S+ & $1058.33 b$ & $145.00 \mathrm{~b}$ & $0.14 b c$ & 0.00 & 47593.33 & $2166.67 c$ & 15500.70 \\
\hline M+PoSo & $413.33 c$ & $37.33 c$ & $0.09 c$ & 56.67 & 44453.33 & $2033.33 d$ & 17989.11 \\
\hline $\mathrm{M}+\mathrm{P}+\mathrm{So}$ & $333.33 d$ & $28.33 c d$ & $0.09 c$ & 40.00 & 48056.67 & $2133.33 c$ & 18711.09 \\
\hline M+PoS+ & $338.33 d$ & $32.67 \mathrm{~cd}$ & $0.10 c$ & 36.67 & 46283.33 & $1766.67 f$ & 19035.90 \\
\hline $\mathrm{M}+\mathrm{P}+\mathrm{S}+$ & $1050.00 \mathrm{~b}$ & $211.00 a$ & $0.20 \mathrm{a}$ & 6.67 & 47140.00 & $2266.67 b$ & 17341.28 \\
\hline $\begin{array}{l}\text { F Value } \\
\text { (Prob.) }\end{array}$ & $\begin{array}{l}214.2652 \\
(<0.0001)\end{array}$ & $\begin{array}{c}123.864 \\
(<0.0001)\end{array}$ & $\begin{array}{l}169.3602 \\
(<0.0001)\end{array}$ & $2.4889(0.137)$ & $\begin{array}{c}1.4984 \\
(0.2411)\end{array}$ & $\begin{array}{l}345.0378 \\
(<0.0001)\end{array}$ & 0.9948 \\
\hline LSD & 70.14 & 11.18 & 0.0554 & 9.063 & 2719 & 65.43 & 649.3 \\
\hline
\end{tabular}

* Different letter implies significant differences in the same column.

Table 1. Continued

\begin{tabular}{|c|c|c|c|c|c|c|c|}
\hline Treatment & $\mathrm{Ca}\left(\mathrm{mg} \mathrm{kg}^{-1}\right)$ & $\begin{array}{l}\mathrm{Mg}\left(\mathrm{mg} \mathrm{kg}^{-}\right. \\
\text {1) }\end{array}$ & $\mathrm{Fe}\left(\mathrm{mg} \mathrm{kg}^{-1}\right)$ & $\mathrm{Zn}\left(\mathrm{mg} \mathrm{kg}^{-1}\right)$ & $\mathrm{Cu}\left(\mathrm{mg} \mathrm{kg}^{-1}\right)$ & $\begin{array}{l}\text { Mn (mg kg- } \\
\left.{ }_{1}^{-}\right)\end{array}$ & $\mathrm{Na}\left(\mathrm{mg} \mathrm{kg}^{-1}\right)$ \\
\hline MoPoSo & $6777.00 f$ & $4771.37 \mathrm{e}$ & $161.48 \mathrm{ef}$ & $121.38 \mathrm{e}$ & $21.04 a$ & $126.89 d$ & 2588.59 \\
\hline MoP+So & $7043.47 \mathrm{e}$ & 4856.87de & $296.47 c$ & $134.08 d$ & $15.30 \mathrm{bc}$ & $154.45 b c$ & 1762.75 \\
\hline MoPoS+ & $6577.43 f$ & 5038.33 cde & $143.77 f g$ & $118.51 \mathrm{e}$ & $21.61 a$ & $108.68 \mathrm{e}$ & 2604.79 \\
\hline MoP+S+ & $7809.67 b c$ & $5228.53 b c$ & 177.10de & $120.64 \mathrm{e}$ & $13.34 d$ & 159.14ab & 1661.00 \\
\hline M+PoSo & $7642.73 c$ & $5322.00 \mathrm{~b}$ & $129.74 \mathrm{~g}$ & $144.19 c$ & $15.56 \mathrm{~b}$ & $150.16 c$ & 1942.67 \\
\hline$M+P+S o$ & $8541.70 a$ & $5680.60 a$ & $458.68 a$ & 188.93a & $12.87 d$ & $164.64 a$ & 1663.25 \\
\hline M+PoS+ & $7345.13 d$ & $5262.57 \mathrm{bc}$ & $439.00 \mathrm{~b}$ & $167.14 b$ & $14.62 c$ & $153.54 b c$ & 1816.71 \\
\hline $\mathrm{M}+\mathrm{P}+\mathrm{S}+$ & $7966.23 b$ & $5073.73 \mathrm{bcd}$ & $184.67 d$ & $120.22 \mathrm{e}$ & $13.27 d$ & $122.84 d$ & 1474.50 \\
\hline F Value & $\begin{array}{l}25.4586 \\
(0.0002)\end{array}$ & $\begin{array}{l}6.5388 \\
(0.0228)\end{array}$ & $\begin{array}{l}712.6051 \\
(<0.0001)\end{array}$ & $\begin{array}{l}256.7127 \\
(<0.0001)\end{array}$ & $\begin{array}{l}19.4614 \\
(0.0006)\end{array}$ & $\begin{array}{l}93.8794 \\
(<0.0001)\end{array}$ & 0.1807 \\
\hline LSD & 264.3 & 273.5 & 19.35 & 5.428 & 0.9398 & 7.535 & 139.1 \\
\hline
\end{tabular}

* Different letter implies significant differences in the same column. 
There were no correlations all the time between the yield and shoot nutrient concentrations due to accumulation- and dilution -effect. In that respect, higher yields compared to lower yields can show increased, decreased or stable shoot nutrient concentrations for any nutrient independent from the others (Table 1 and Figure 1,2,3). There are some reports pointing out such treatment induced ambiguities in nutrient concentrations (Karaca, 2014; Karaca, 2012a; Karaca, 2012b; Yibirin et al., 1996).

Those results above indicate that different treatments in the growth media affect the efficient use of nutrients and mycorrhizae with the subsequent yield differences.

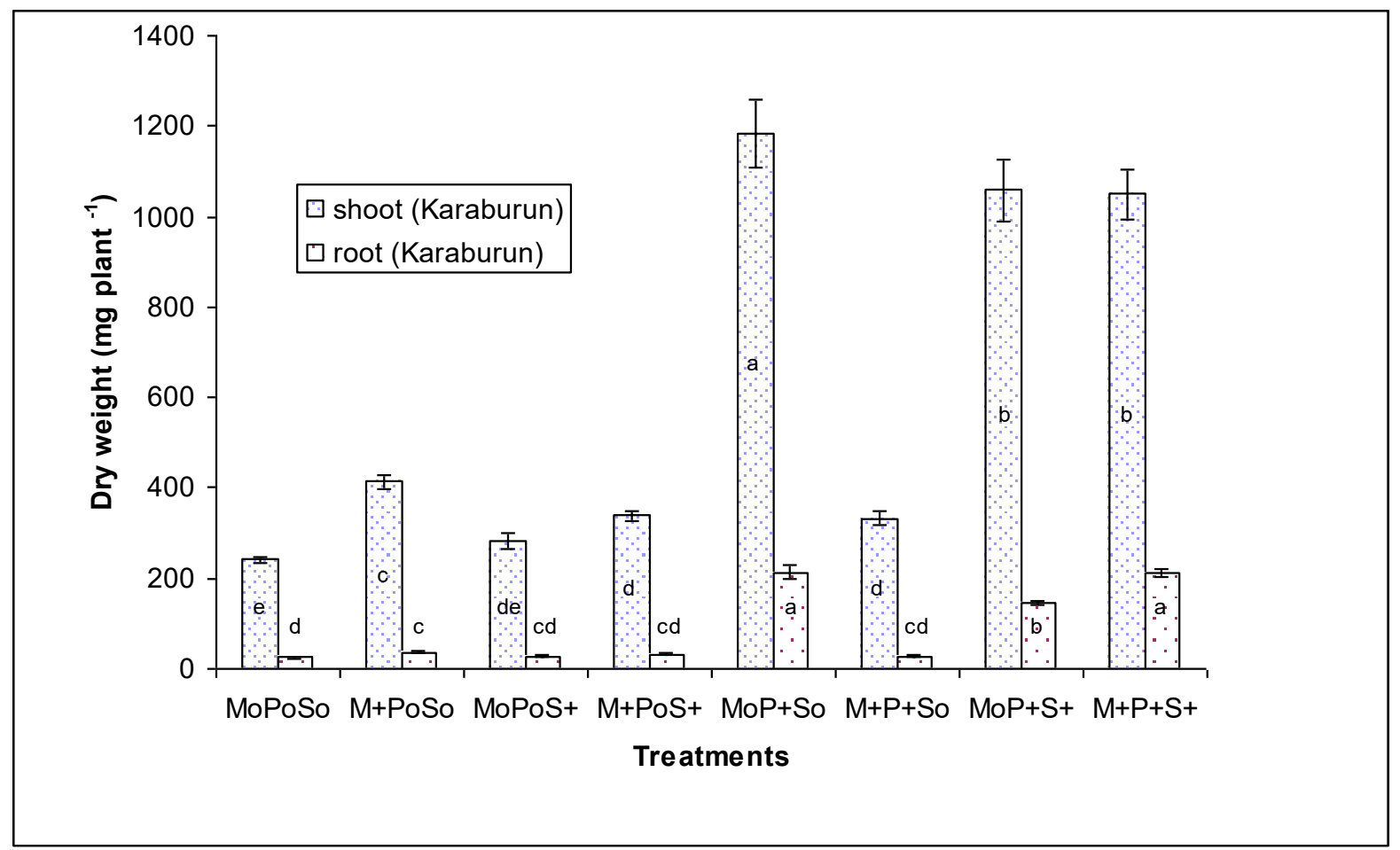

Figure 1. Pepper shoot and root dry weight biomasses. Different letters indicate significant difference between the treatments. Error bars indicate standard deviation.

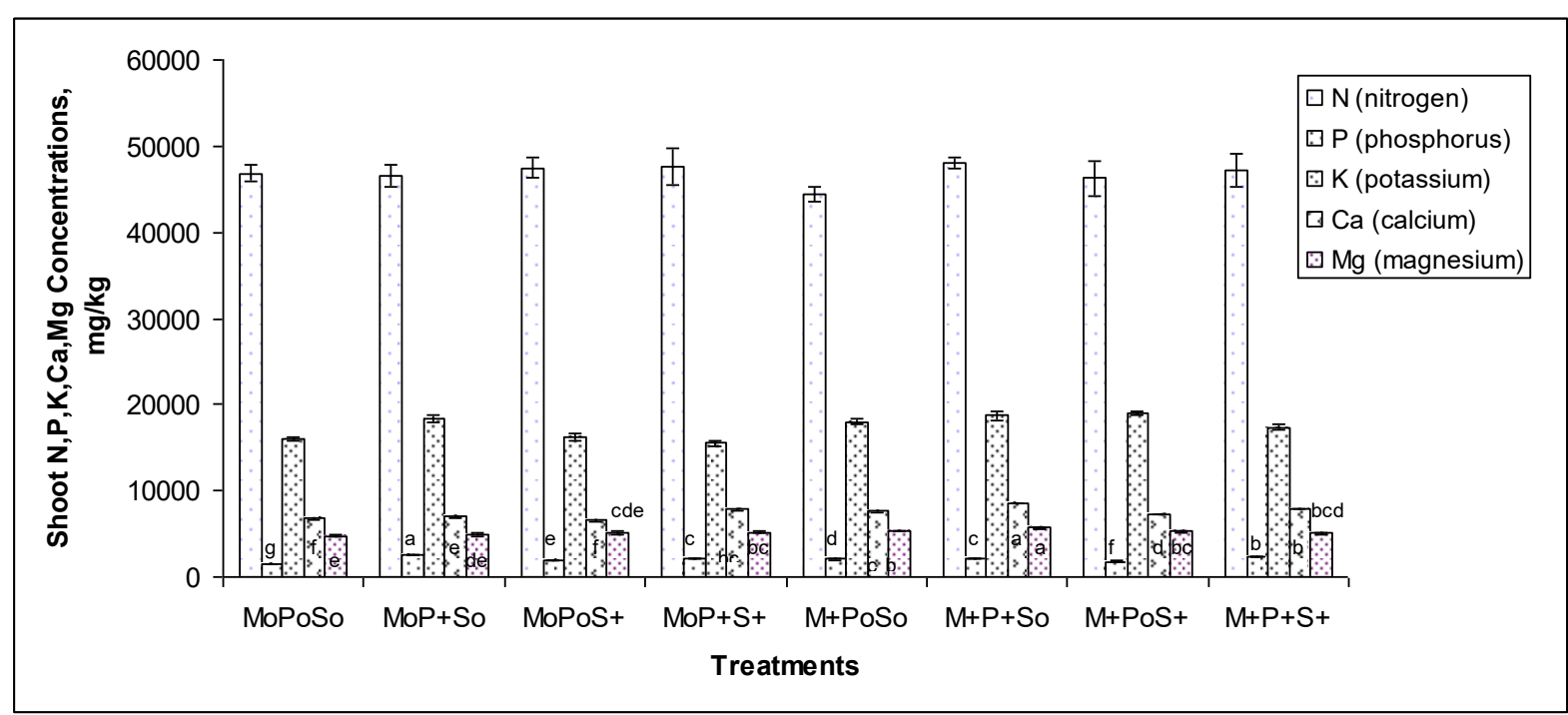

Figure 2. N, P, K, Ca, Mg concentrations of pepper shoots. Different letters indicate significant difference between the treatments. Error bars indicate standard deviation. 


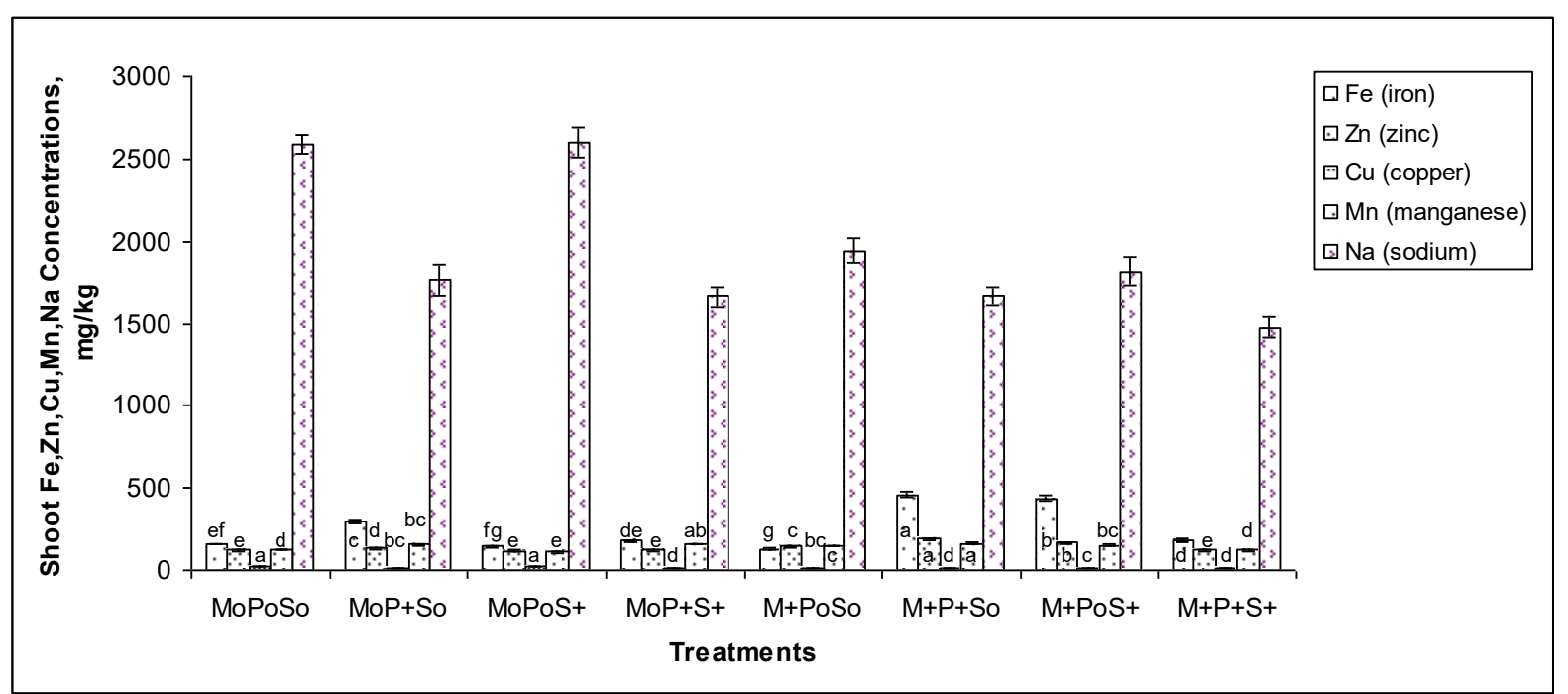

Figure 3. $\mathrm{Fe}, \mathrm{Zn}, \mathrm{Cu}, \mathrm{Mn}, \mathrm{Na}$ concentrations of pepper shoots. Different letters indicate significant difference between the treatments. Error bars indicate standard deviation.

Root Mycorrhizal Infection Responses to ES, $P$ and Mycorrhizal Inoculation

None of the non-inoculated plants exhibited any mycorrhizal structures (Table 1 and Figure 4). In the mycorrhizal treatments, the highest root mycorrhizal infection level was obtained by M+PoSo treatment as $56.67 \%$. Phosphorus supplement with mycorrhizae reduced the infection ratio to $40 \%$ that similar responses were also reported by Karaca (2012a). Sulfur addition also resulted in similar decreasing trend (36.7\%) as observed for M+PoS+ treatment (Figure 4) which is not consistent with the previous findings (Diaz et al., 1996).
Nevertheless, as small as $6.67 \%$ mycorrhizal infection was recorded for $\mathrm{M}+\mathrm{P}+\mathrm{S}+$ treatment that yielded maximun crop biomass. Those findings indicate that individual and co-effect of $P$ and $E S$ treatments have negative effects on mycorrhizal infection but only their individual effects resulted in yield decreases. Those yield decreases were compensated to a great extent by getting decreased of root mycorrhizal infection percentage to the lowest level (Table 1 and Figure 1,4) being not consistent with the previous findings (Karaca, 2012a).

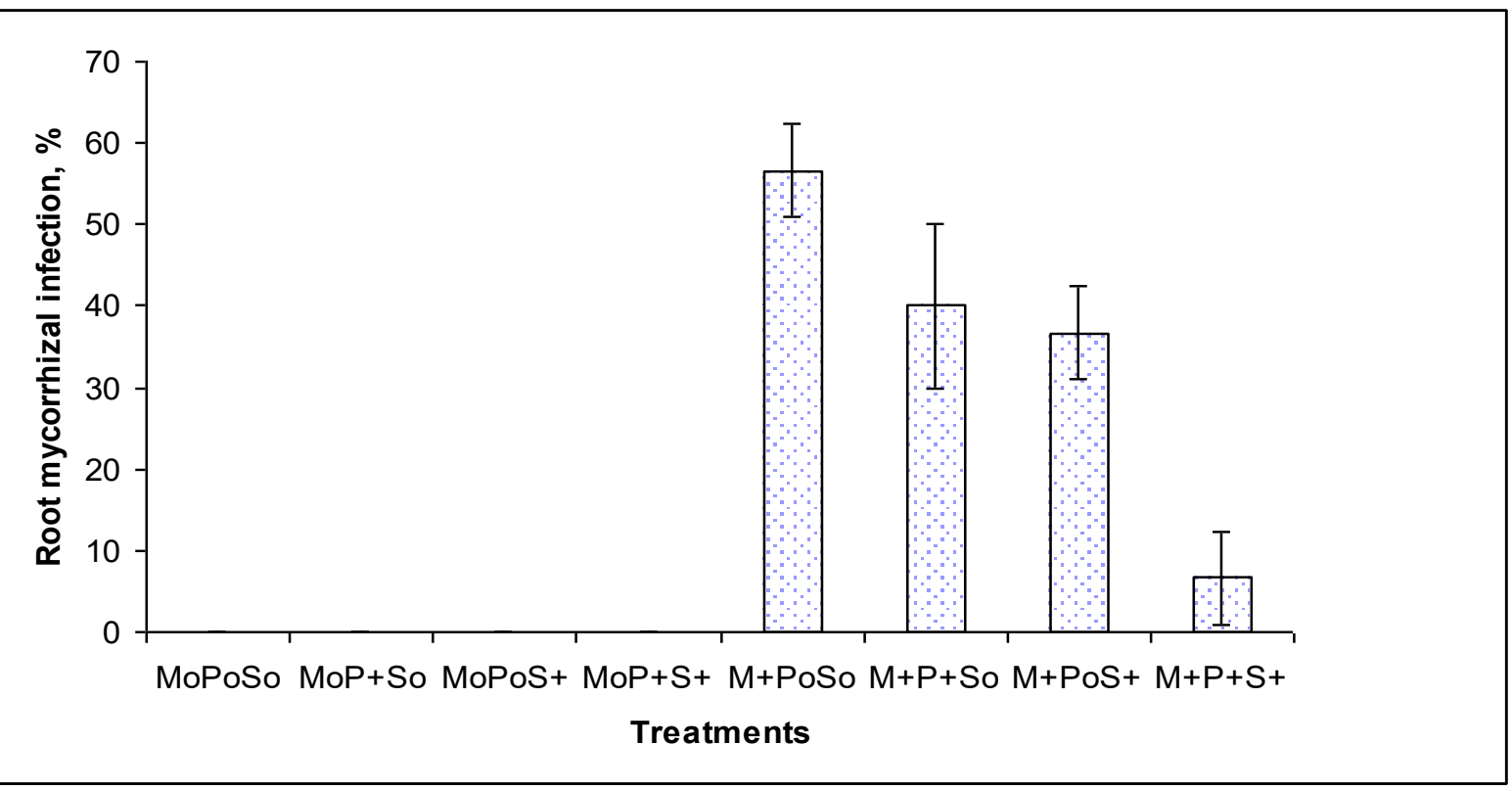

Figure 4. Treatment induced mycorrhizal infection percentages. Different letters indicate significant difference between the treatments. Error bars indicate standard deviation. 


\section{Root : Shoot ratio}

M+PoSo treatment compared to the MoPoSo one did not affect the root to shoot ratio. On the other hand, the ratios responded in both directions among the other all treatments. Those findings are similar to the findings (Karaca, 2012a; Karaca, 2014) who reported that root: shoot ratio decreases or remains around at the same level between mycorrhizal inoculation alone and control treatment but root to shoot ratio changes in both directions by either ES or P fertilizations. Moreover, there were no straightforward relations between yield and root to shoot ratio (Karaca et al., 2013). Accordingly, higher yield compared to lower one may have higher, lower or costant root to shoot ratio as presented in Table 1 and Figure 1 and 5 . Those changed ratios may lend support also to the hypothesis (Romero et al., 1996) who proposed that there may be an optimum R: $\mathrm{S}$ ratio for plant growth. The other point is when the plant have readily accessed to plant nutrient promote shoot growth rather than the root growth.

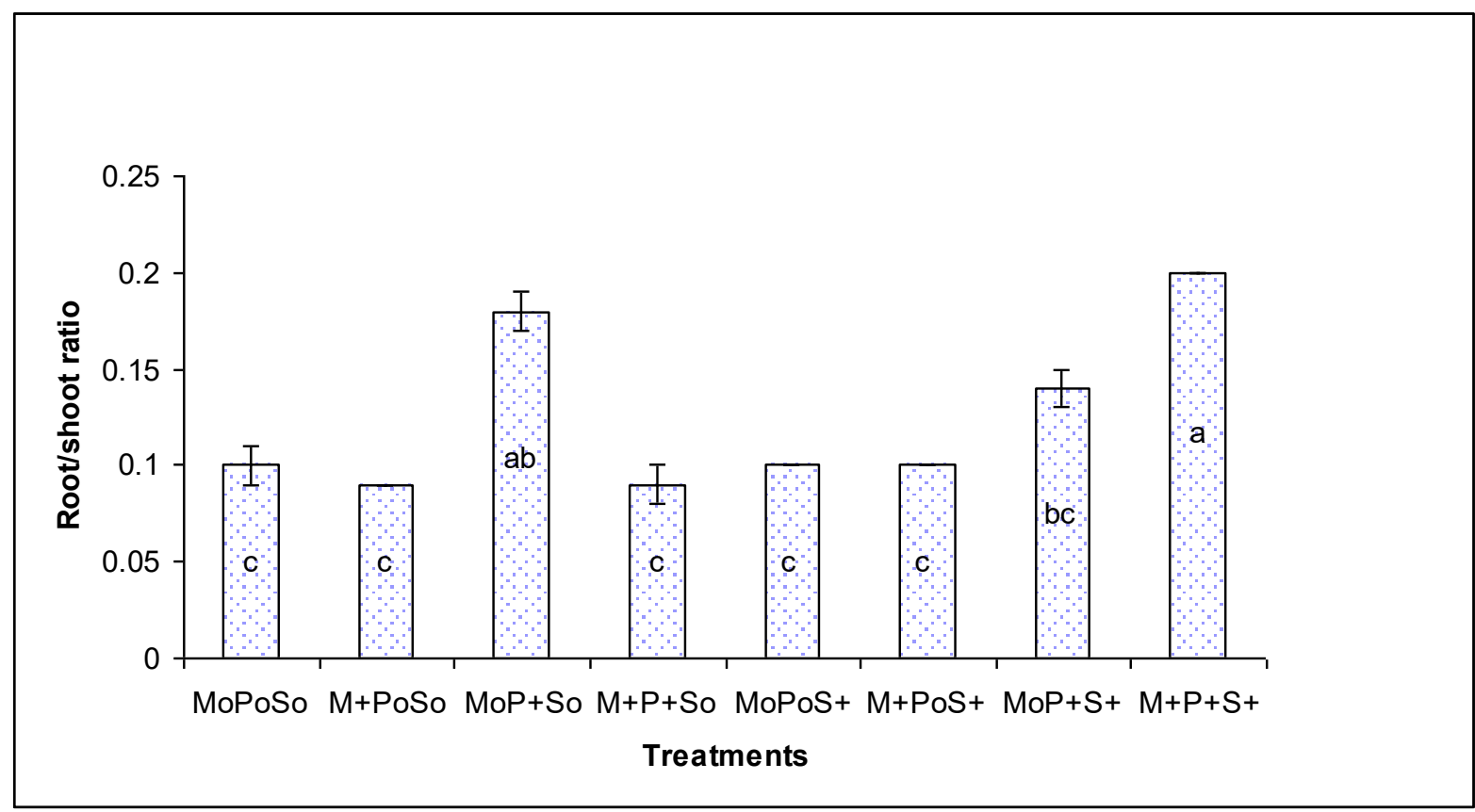

Figure 5. Root to shoot ratio (dry weight) of pepper plant under different treatments. Different letters indicate significant difference between the treatments. Error bars indicate standard deviation.

\section{CONCLUSIONS}

Yield increases were obtained by $\mathrm{P}$ addition same as ES addition in the non-mycorrhizal treatments. The highest yield was obtained by $P$ addition alone. That highest yield level decreased by combination effect of ES and $P$ addition indicating antagonistic effect between ES and $P$. While mycorrhizal inoculation increased yield, both $P$ addition alone and elemental $\mathrm{S}$ addition alone resulted in significant yield decreases in the mycorrhizal treatments indicating the negative effect of ES or $P$ on mycorrhizae. On the other hand, ES and $\mathrm{P}$ addition in combination resulted in the highest yield in the mycorrhizal treatments as response to the lowest root mycorrhizal infection level. Phosphorus, $\mathrm{Ca}, \mathrm{Mg}, \mathrm{Fe}, \mathrm{Mn}$, $\mathrm{Zn}$ and $\mathrm{Cu}$ shoot concentrations independently changed from each other in both direction.

ES or $P$ addition decreased insignificantly root mycorrhizal infection level while root to shoot ratios changed in both directions.

From all above it can be concluded that $\mathrm{P}$ and/or ES additions require to be regulated well in the changing growth medium conditions to get higher yield in agricultural production system.

\section{ÖZET}

Amaç: Gübreleme tarımda verime katkı sağlar. Bu çalışmanın amacı yeşil biber (Capsicum annuum L.) verimi, kök/sürgün oranı, besin elementi alımı kökle mikorizanın infekte olma düzeyi üzerinde mikoriza ve elemental kükürt $(E S)$ ve fosfor $(P)$ gübrelemesinin etkisini belirlemekti.

Yöntem ve Bulgular: $100 \mathrm{mg} / \mathrm{kg}$ ES and/or $100 \mathrm{mg} / \mathrm{kg} \mathrm{P}$ gübreleri mikorizalı ve mikorizasız toprağa ilave edildi. 45 gün süreyle yeşil biber bitkisi kireçli sterilize edilmiş Karaburun toprağında yetiştirildi. Kök ve sürgün verimi mikoriza aşılaması ile control uygulamasına göre arttı. 
Tek başına ES yada $P$ gübrelemesiyle mikorizasız uygulamalarda verim artarken, mikorizalı uygulamalarda tersi durum söz konusu idi. ES and $P$ gübrelemesi birlikte tek başına $P$ gübrelemesine kıyasla mikorizasız uygulamalarda verimi düşürürken, mikorizalı uygulamalarda tersi durum söz konusu idi. Kök sürgün oranı ve sürgün besin elementi konsatrasyonu verimden ve uygulamalardan bağımsız olarak iki yönlü değişim gösterdi. ES ve/veya $\mathrm{P}$ ilavesi mikorizal infekte olma düzeyini önemsiz düzeyde azalttı.

Genel Yorum: Elde edilen bulgular gösteriyor ki ES and/or $\mathrm{P}$ gübrelemesi kökle mikorizanın infekte olma düzeyini önemsiz ölçüde azaltmakla birlikte yeşil biber verimini, besin elementi alımını, kök sürgün oranını iki yönde etkilemektedir.

Çalışmanın Önemi ve Etkisi: ES and/or P gübrelemesi mikoriza aşılamasıyla birlikte daha yüksek ürün elde etmek için önemlidir. Bu nedenle bu çalışma biberde verim kayıplarını önlemek için mikorizalı ve mikorizasız yetiştirme koşullarında uygun gübre ve gübre kombinasyonları hakkında bilgi sağlamaktadır.

Anahtar Kelimeler: Mikoriza, elementel kükürt, fosfor, sürgün element konsantrasyonları, biber verimi.

\section{ACKNOWLEDGEMENTS}

This project was partially funded by Cukurova University Research Foundation. Appreciation is extended to the workers of Institute of Applied Sciences, Mustafa Kemal University for their help in digesting and analyzing plant samples. Special thanks to the electronic engineer Atilla ÇEKiÇ for taking the root microphotographs.

\section{CONFLICT OF INTEREST DECLARATION}

The author(s) declare no conflict of interest for this study.

\section{REFERENCES}

Al Karaki GN (1998) Benefit, cost and water-use efficiency of arbuscular mycorrhizal durum wheat grown under drought stress. Mycorrhizae 8: 41-45.

Antunes V, Cardose EJBN (1991) Growth and nutrient status of citrus plants as influenced by mycorrhizae and phosphorous application. Plant and Soil 131: 1119.

Blake GR, Hartge KH (1986a) Bulk density. In Methods of Soil Analysis. Part 1. Physical and mineralogical methods (Ed. Klute A (2 ${ }^{\text {nd }}$ Edn.), Madison, WI: SSSA Book Series 5. pp 363-375.
Blake GR, Hartge KH (1986b) Particle density. In Methods of Soil Analysis. Part 1. Physical and mineralogical methods (Ed. Klute A ( ${ }^{\text {nd }}$ Edn.), Madison, WI: SSSA Book Series 5. pp 377-382

Bouyoucos GJ (1951) A recalibration of the hydrometer method for making mechanical analysis of soils. Agron J. 43: 434-438.

Bremner JM (1996) Nitrogen-total. In: Method of Soil Analysis. Part 3. Chemical Methods (Eds. Sarks DL, Page AL, Helmke PA, Loeppert RH, Soltanpour PN, Tabatabai MA , Johnston $C T$, Sumner ME), Madison, WI: SSSA. pp 1085-1122.

Cui Y, Dong Y, Li H, Wang Q (2004) Effect of elemental sulfur on solubility of soil heavy metals and their uptake by maize. Environ. Int. 30(3): 323-328.

Diaz G, Barrantes O, Honrubia M, Gracia C (1996) Effect of ozone and sulfur dioxide on mycorrhizae of Pinus halepensis miller. Ann. Sci. Forest. 53: 849-856.

Fabig W, OttowJ CG, Muller F (1978) Mineralisation von 14C-Markiertem Benzoat Mit Nitrat als WasserStoffakzeptor unter Vollstandig Anaeroben Bedingungen Sowie Bei Vermindertem Sauerstoffpartialdruck [Mineralization of 14C-labeled benzoate with nitrate as water under completely anaerobic conditions, as well as partially reduced oxygen]. Landwirstschaft Forschung, 35: 441-453.

Fachgruppe Wasserchemie in der Gesellscheft Deutscher Chemiker (1983) Deutsche Einheitsverfahren Zur Wasser-Abwasser-und Schlammuntersuchungen [German Standart Methods for Water, Wastewater and Sludge Tests]. Weinheim: Verlag Chemie.

Gerdemann JW, Nicolson TH (1963) Spors of mycorrhizal endogeny species extracted from soil by wet sieving and decanting. Trans. Brit. Mycol. Soc. 46: 235-244.

Kacar B (1972) Chemical analysis of soil and plant (in Turkish). Ankara, Turkey: Ankara University Agricultural Press 453.

Karaca H (2012a) Buffering effect of elemental sulfur on mycorrhizal infection of leek. J. Plant Nutr. 35(5): 678687.

Karaca H (2012b) Efficiency of elemental sulfur on mycorrhizae in the yield increase of wheat. J. Plant Nutr. 35(8): 1225-1233.

Karaca H, Uygur V, Özkan A, Kaya Z (2013) The effects of mycorrhizae and fertilization on soybean yield and nutrient uptake. Commun. Soil Sci. Plant Anal. 44: 2459-2471.

Karaca H (2014) Effects of elemental sulfur and mycorrhizae on the yield of wheat in different soils. J. Plant Nutr. 37: 1-15. 
Klute A, Dirksen C (1986) Hydraulic Conductivity and Diffusivity: Laboratory Methods. In Methods of Soil Analysis. Part 1. Physical and mineralogical methods (Ed. Klute A ( $2^{\text {nd }}$ Eds.). Madison, WI: SSSA Book Series 5.

Koske RE, Gemma JN (1989) A modified procedure for staining roots to detect VAM. Mycol. Research 92: 486-505.

Lees R (1971) Laboratory Handbook of Methods of Food Analysis. London: Leonard Hill Books.

Lindsay WL, Norwell WA (1978) Development of DTPA for soil test zinc, iron, manganese and copper. Soil Sci. Soc. Am. J. 42: 421-428.

Loeppert RH, Suarez DL (1996) Carbonate and gypsum. In: Method of soil analysis. Part 3. Chemical methods [Eds. Sarks DL, Page AL, Helmke PA, Loeppert RH, Soltanpour PN, Tabatabai MA, Johnston CT, Sumner ME], Madison, WI: SSSA, pp 437-474

Mohammed A, Mitra B, Khan AG (2004) Effects of sheared-root inoculum of Glomus intraradices on wheat grown at different phosphorous levels in the field. Agric. Ecosys. Environ. 103(1):245-249.

Murphy J, Riley JP (1962) A modified single solution method for the determination of phosphate in natural waters. Anal. Chim. Acta. 27:31-36.

Olsen SR, Cole CV, Watanable FS, Dean LA (1954) Estimation of available phosphorus in soils by extraction with sodium bicarbonate. USDA Circular 939. Washington, DC: US Government Printing Office.
Ortas I, Rowell DL, Haris PJ ( 2004) Effect of mycorrhizae and $\mathrm{pH}$ change at the root-soil interface on phosphorus uptake by sorghum using a rhizocyclinder technique. Commun. Soil Sci. Plant Anal. 35:10611080.

Ozbek H, Dinc U, Kapur S (1974) Detailed basic survey and mapping of the soils of Cukurova University settlement area (in Turkish). Cukurova University Agricultural Faculty publication 73. Adana, Turkey: Cukurova University.

Pratt PF, Morse HH (1954) Potassium release from exchangeable and non-exchangeable forms in Ohio soils. Ohio Agricultural Experiment Station Research Bulletin 747. Columbus, $\mathrm{OH}$ : Ohio State University.

Romero A, Ryder J, Fisher JT, Mexal JG (1986) Root system modification of container stock for arid land plantings. Forest Ecology and Management 16: 281290.

Schlichting E, Blume H (1966) Bodenkundliches Practikum [Soil Science Handbook]. Berlin: Paul Parey Verlag.

U.S. Salinity Laboratory Staff (1954) Diagnosis and improvement of saline and alkali soils. USDA Handbook 60. Washington, DC: U.S. Government Printing Office.

Yibirin H, Johnson JW, Eckert D (1996) Corn production as affected by daily fertilization with ammonium, nitrate, and phosphorous. Soil Sci. Soc. Am. J. 60: 512518. 